\title{
Dialectic as Ostension Towards the Transcendent: Language and Mystical Intersubjectivity in Plotinus' Enneads
}

\author{
Albert R. Haig | ORCID: 0000-0002-3436-6890 \\ Independent Scholar, Townsville, Australia \\ albert.haig@gmail.com
}

\begin{abstract}
The theory of language that underlies Plotinus' Enneads is considered in relation to his broader metaphysical vision. For Plotinus, language is neither univocal nor equivocal, but is something in-between, incapable of precisely describing reality, but nonetheless not completely useless. Propositional knowledge expressed discursively represents an imperfect shadow of reality which is defective in relation to the pure apprehension of Intellect. Passages in Plotinus which relate language to the sensible world are examined and it is argued that, although it plays a useful role in relating the sensible world to Intellect, discursive reason is nonetheless intrinsically inferior to both as a mode of representation. Plotinus holds that the inadequacy of language is "global" in character; language cannot describe any aspect of reality precisely, from the mundane to the transcendent. Language as a whole is an inferior image or imitation of the world as a whole. Therefore, the flaws in our linguistic representations cannot all be untangled or conceptually unpacked by means of language. There are passages in the Enneads which hint at an underlying semantic holism. Plotinus' theory implies that apparent verbal contradictions which occur in different contexts might nonetheless still represent the optimal linguistic description of a reality that strictly speaking is ineffable. Therefore, discursive logical deduction is not always reliable, and needs to be subordinated to a vision of Intellect. True philosophical reasoning (dialectic) represents ostension towards the transcendent. Those who are sufficiently liberated to attain to an apprehension of the Forms, thereby come to inhabit the same "higher world", involving a shared mystical intersubjectivity, which can be expressed linguistically, but only in an approximate manner. Plotinus' theory presents a potential way out of the nihilistic impasse into which contemporary philosophy has arguably become enmeshed.
\end{abstract}




\section{Keywords}

Plotinus - Neoplatonism - semantics - language - mysticism - intersubjectivity

\section{Introduction: Plotinus and the Inadequacy of Language}

Joseph Dan has argued that the defining characteristic of mysticism is the belief that ultimate reality cannot be described in language. He writes, "The mystic is someone who knows that real truth, meaningful truth, can never be fully expressed in words ... Only the trivial, or the false, can be communicated and understood. Truth is beyond comprehension ...."1 Nonetheless, moderate forms of mysticism are possible, which attempt to inhabit a middle ground between the univocal and the equivocal. In these forms of mysticism, language is seen as neither entirely useless, nor completely adequate, for the purpose of metaphysical description, but as somewhere in-between. It will be argued here that Plotinus can be considered to inhabit this middle ground of moderate mysticism.

Since, as Hamann famously quipped, Vernunft ist Sprache ("reason is language"), ${ }^{2}$ the mystic's scepticism about language typically results in a distrust of discursive reason. The present work will attempt to demonstrate that just such a scepticism, in a moderate form, is evident in Plotinus' Enneads I.3 ("On Dialectic"), and in the many other instances where Plotinus stresses that his words are not to be taken too literally. Such a scepticism is at least incipient in the writings of Plato himself. However, in Plotinus the idea of language as situated in a middle ground between univocity and equivocity, becomes highly developed. Language, according to Plotinus, represents merely an "imitation" $\left(\mu i \mu \eta \mu \alpha^{3}\right)$ of ultimate reality, that cannot precisely capture its essence.

The purpose of this paper is to analyse the understanding of language found in Plotinus' Enneads, and how this understanding is situated within the broader scope of the metaphysical system he envisages. This begins with a consideration of Plotinus' outlook on the limitations of language in relation to metaphysical description. It is argued that Plotinus' theory of linguistic inadequacy is global in character, regarding linguistic description as always necessarily inadequate and "approximate", whether applied in relation to mundane or transcendent realities. Some of the implications of this semantic theory are

1 J. Dan (2002) 3-4.

2 J.R. Betz (2012) 33 o.

3 Plotinus, Enn., I.2.3. 
then explored, especially in relation to the constraints it imposes in relation to deductive logical inference. It is argued that Plotinus sees true philosophy, or "dialectic" ( $\delta\left(\alpha \lambda \varepsilon \kappa \tau i x \eta^{\prime}\right)$, as ostension towards the transcendent; as a means of verbally indicating towards a non-linguistic vision of Intellect and the One. He expresses a theory of mystical intersubjectivity, in which those who achieve such a vision can be said to inhabit a common "higher world". Finally, the relevance of Plotinus' thought in a contemporary context is considered. It is argued that Plotinus' perspective remains relevant and offers a promising alternative to the current "postmodern" philosophical quagmire.

The Deficiencies of Metaphysical Description According to Plotinus

The idea that linguistic descriptions of metaphysical reality cannot be entirely precise has a long history in the Platonic tradition. It originates in the writings of Plato himself, in several texts which caution against taking words too literally when speaking of ultimate reality. For example, "so far as it lies in words to be incontrovertible and immovable, they must in no wise fall short of this ... If then ... we should not prove able to render an account everywhere and in all respects consistent and accurate, let no one be surprised." ${ }^{4}$ Again, "All that is said by any of us can only be imitation and representation ... Wherefore if at the moment of speaking I cannot suitably express my meaning, you must excuse me..... ${ }^{5}$ In these passages Plato seems to express a belief in the inadequacy and limitedness of language, at least when pressed into the service of metaphysical description, of "the heavens and things divine". 6 The extent and nature of this scepticism about language in Plato is not a matter which needs to be resolved here. ${ }^{7}$ However, it does serve as important contextual background to the far more developed and explicit discussions in Plotinus about the limitations of language.

Plotinus' scepticism about the adequacy of language, and his consequent employment of it in a merely "approximate" or loose "rough and ready" fashion, is most obvious when he discussed the principle which is most remote from ordinary experience, the One ( $\tau \dot{\partial} \tilde{\varepsilon} v) /$ the Good ( $\tau \dot{\alpha} \gamma \alpha \theta 0 v)$. He repeatedly qualified statements about the One by saying that they should not be understood

\footnotetext{
4 Plato, Tim., 29c (trans. R.D. Archer-Hind, 89-91).

5 Plato, Criti., 107c,e (trans. B. Jowett, 789-9o).

6 Ibid.

7 See E. Benitez (1995).
} 
too literally. So, for example, he wrote, "So in a loose and general way of speaking ( $\left.\delta \lambda \circ \sigma \chi \varepsilon p \varepsilon \hat{\imath} . . . \lambda \delta^{\prime} \gamma \omega\right)$ the Good is the primary beauty"; "But when we use the word "always"... we must be thought to be putting it this way for our own

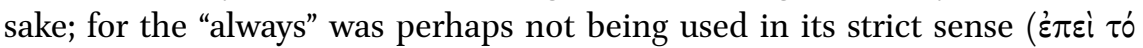

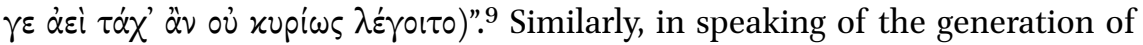
Intellect from the One, Plotinus found it necessary to employ language loosely

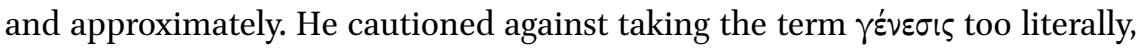
for example. ${ }^{10} \mathrm{He}$ even warned against an overly literal understanding of the

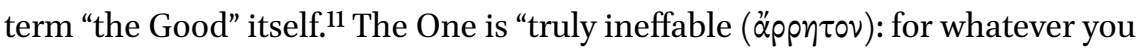
say about it, you will always be speaking of a "something"'.12 It "has no name", and we "try, as far as possible, to make signs to ourselves about it". ${ }^{13}$ Even "the One" is not adequate as a name ("it is false even to say of it that it is one, and there is "no concept or knowledge of it"'14). Plotinus reflected, "But we in our travail do not know what we ought to say, and are speaking what cannot be spoken, and give it a name because we want to indicate it to ourselves as best we can". ${ }^{15}$ The nature of the One can be conveyed by means of both analogy and negation: "We are taught about it [the One] by comparisons ( $\alpha \nu \alpha \lambda \circ \gamma i \alpha \mathrm{l})$

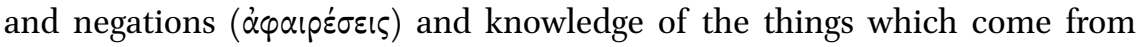
it and certain methods of ascent by degrees ...."16 The limitations of language in describing the Good, entail that the Good itself does not think. It could not think anything accurately about itself in language. Even the word "is" cannot properly be applied to it. ${ }^{17}$ Plato himself, Plotinus claimed, could not describe the Good in precise terms ("he [Plato] could not explain what he meant in any other way"18). The Good "transcends thought"; 19 Plotinus doubted that "discourse can indicate it in any way at all", ${ }^{20}$ for "it is impossible to think the Good". ${ }^{21}$ Quoting from the Parmenides, he noted, "'There is neither discourse

Plotinus, Enn., I.6.9 (trans. Armstrong, 261).

9 Plotinus, Enn., III.7.6 (trans. Armstrong, 315).

10 Plotinus, Enn., V.1.6.

11 Plotinus, Enn., v.3.11.

12 Plotinus, Enn., v.3.13 (trans. Armstrong, 117).

13 Ibid.

14 Plotinus, Enn., V.4.1 (trans. Armstrong, 141). See also vi.2.11.

15 Plotinus, Enn., v.5.6 (trans. Armstrong, 175).

16 Plotinus, Enn., VI.7.36 (trans. Armstrong, 199).

17 Plotinus, Enn., VI.7.38.

18 Plotinus, Enn., vi.7.39 (trans. Armstrong, 209).

19 Ibid.

20 Plotinus, Enn., Vi.7.40 (trans. Armstrong, 209).

21 Plotinus, Enn., VI.7.40 (trans. Armstrong, 213).
} 
nor perception nor knowledge" because it is impossible to predicate anything of it [the One] as present with it". ${ }^{22}$

Enneads vi.8-9 are full of similar claims about the One. The Good cannot be "defined" in this or that way - "But, since you see it as without definition, you will be able to speak of all the things which come after it, but you will affirm that it is none of these .... ${ }^{23}$ Not only positive affirmations, but even negations, are inadequate to describe the Good. ${ }^{24}$ There is a point at which all attempts at linguistic explanations of the One must be left aside as deficient: "one must stop here and say nothing more about him [the One]";25 "We must go away in silence and enquire no longer [about the One], aware in our minds that there is no way out". ${ }^{26}$ It is "not correct" to use "names of what we are looking for". ${ }^{27}$ Every statement about the One must be qualified with an "as if" (oiov): "But one must go along with the words, if one in speaking of that Good uses of necessity to indicate it expressions which we do not strictly speaking allow to be used; but one should understand "as if" with each of them". ${ }^{28}$ When a person sees the One "he will put away all reasoning", "nor is he able to utter a word about it". 29 The One is something "about which it is not possible any more to say or apprehend anything else". ${ }^{30}$ Strictly speaking one should not say even "that" or "is" about it. ${ }^{31}$ The One "in truth has no fitting name", ${ }^{32}$ and even "One" is not used of it in the ordinary sense. ${ }^{33}$

It is clear, therefore, that, at least when talking about his first principle, Plotinus believed that language could occupy a space between univocity and equivocity. However, although Plotinus' most striking remarks about the shortcomings of language relate to descriptions of the One, he also spoke of language as being limited and merely approximate in character when describing lower levels of metaphysical reality such as the soul. For example, "For weakness in the soul is not just like that in bodies; but incapacity for work and being easily affected, as in the body, so by analogy $(\alpha \nu \alpha \lambda \circ \gamma i \alpha)$ in the soul has the name

\footnotetext{
22 Plotinus, Enn., VI.7.41 (trans. Armstrong, 217).

23 Plotinus, Enn., vi.8.9 (trans. Armstrong, 257).

24 Plotinus, Enn., vi.8.9.

25 Plotinus, Enn., Vi.8.10 (trans. Armstrong, 259).

26 Plotinus, Enn., vi.8.11 (trans. Armstrong, 261).

27 Plotinus, Enn., vi.8.13 (trans. Armstrong, 267).

28 Plotinus, Enn., vi.8.13 (trans. Armstrong, 271).

29 Plotinus, Enn., vi.8.19 (trans. Armstrong, 291).

30 Plotinus, Enn., Vi.8.21 (trans. Armstrong, 297).

31 Plotinus, Enn., vi.9.3.

32 Plotinus, Enn., VI.9.5 (trans. Armstrong, 321).

33 Plotinus, Enn., Vi.9.5 (trans. Armstrong, 321-3).
} 


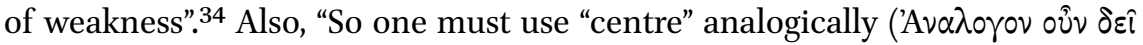
$\tau \dot{~} \mu_{\varepsilon} \varepsilon \sigma 0 v$ ); for there must be a centre for soul as there is for body". ${ }^{35}$ The terms "inside" ( $\varepsilon l \sigma \omega)$ and "outside" ( $\xi \xi \omega)$ are also used loosely, and not literally. ${ }^{36}$ Words used to describe sensible reality can only be used "analogously and

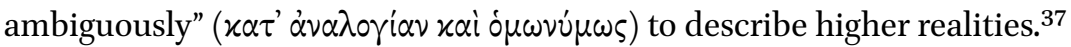

Plotinus maintained that there is a fundamental difference between the true knowledge of Intellect, on the one hand, and propositional knowledge expressed through discursive reasoning, on the other. The latter is greatly deficient in comparison to the former. For example, "intellect there [in the intelligible realm] is not the sort one might conceive on the analogy of our so-called intellects which get their content from premises and are able to understand what is said, and reason discursively and observe what follows, contemplating reality as the result of a process of reasoning"; 38 "there must be in us Intellect which does not reason discursively". ${ }^{39}$ Discursive reason employed to describe metaphysical realities is like mythology, because "rational discussions, also [like myths], make generations of things ungenerated, and themselves, too, separate things which are together". 40 The use of language is intrinsically linked to time, and prior to Soul's entry into time "discursive thought was not in action". 41 "Does the soul use discursive reasoning before it comes and again after it goes out of the body? No, discursive reasoning comes into it here below ...."42 Language is not used in the intelligible world: "Nor do I think that we should suppose that they use speech in the intelligible world ..."; "feeling the need of reasoning is a lessening of the intellect". 43 In Intellect "there is no discursive thought or transition from one to the other" ${ }^{44}$ For the intelligible,

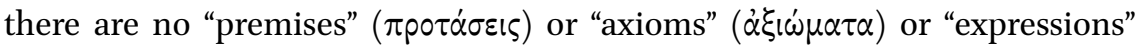
$(\lambda \varepsilon \varkappa \tau \dot{\alpha}) \cdot{ }^{45}$ Intellect does not follow "a train of logical consequences and purposive thought ... all this comes later, reasoning and demonstration .... ${ }^{46}$ Intellect

Plotinus, Enn., I.8.14 (trans. Armstrong, 311).

Plotinus, Enn., II.2.2 (trans. Armstrong, 47).

38 Plotinus, Enn., I.8.2 (trans. Armstrong, 281).

39 Plotinus, Enn., v.1.11 (trans. Armstrong, 49).

40 Plotinus, Enn., III.5.9 (trans. Armstrong, 201).

41 Plotinus, Enn., III.7.11 (trans. Armstrong, 341).

42 Plotinus, Enn., IV.3.18 (trans. Armstrong, 91).

43 Ibid.

44 Plotinus, Enn., IV.4.1 (trans. Armstrong, 137). See also IV.8.1, "when I have come down from Intellect to discursive reasoning ...” (trans. Armstrong, 397).

45 Plotinus, Enn., V.5.1.

46 Plotinus, Enn., v.8.7 (trans. Armstrong, 261-3). 
possesses knowledge "as in thought, but not the discursive kind of thought". 47 There is no "rationality" ( $\tau \dot{\partial} \lambda$ orixóv) in Intellect, "for here perhaps man is rational but in that world there is the man before reasoning". 48

\section{The Inferior Position of Language in Plotinus' Metaphysical Hierarchy}

The application of the term "hierarchy" to Plotinus' ontology, though widespread, ${ }^{49}$ is controversial because of the broader connotations of this term, many of them seen as negative in a modern context. O'Meara argues, for instance, that "The expressions 'hierarchy' and 'chain of being' are both too vague and too open to anachronism to be useful in coming nearer to Plotinus' views". ${ }^{50}$ He prefers to employ Plotinus' terminology of "priority" and "posteriority". However, Plotinus also speaks in terms of higher and lower, ${ }^{51}$ as well as

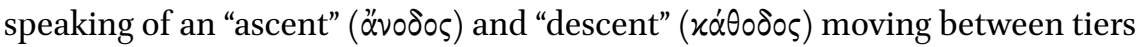
of reality. ${ }^{52}$ Therefore, in what follows the term hierarchy will be used, but with the caveat that this implies nothing more than a structured ordering of reality from that which is "higher" or "prior" to that which is "lower" or "posterior".

Plotinus, due to the nature and purpose of his writings, mainly commented about language in relation to higher metaphysical realities such as Intellect and the One. He was not overly concerned with developing an explicit theory of what we might call "ordinary language", or of language as it applies to the sensible world in everyday discourse. Furthermore, there is disagreement concerning the extent to which Plotinus was a direct realist about the sensible world, as opposed to some kind of subjectivist or idealist. ${ }^{53}$ For present purposes that debate can be side-stepped, and the question can be framed like this: does language capture the exact nature of the sensible world (either as it really is, or its subjective representation in perception), or is it only a rough "imitation" of the sensible world? In hierarchical terms, is language as a means of representation on the "same level" as the sensible world, or is it "below" it?

A crucial passage in this regard is found in Enneads I.2:

\footnotetext{
47 Plotinus, Enn., VI.2.21 (trans. Armstrong, 171).

48 Plotinus, Enn., vi.7.9 (trans. Armstrong, 113).

49 M. Gatti (1996) 24-25.

$50 \quad$ D. O'Meara (1996) 78.

51 A.H. Armstrong (1993) 122 (footnote 1).

52 Plotinus, Enn., VI.4.16.

53 E. Emilsson (1996) 231.
} 


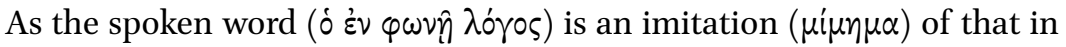
the soul ( $\dot{\varepsilon} v \psi v \times \hat{n})$, so the word in the soul is an imitation of that in something else: as the uttered word, then, is broken up into parts as compared with that in the soul, so is that in the soul as compared with that before it [Intellect], which it interprets. ${ }^{54}$

A similar passage is found in v.1: "just as a thought in its utterance is an image of the thought in soul, so soul itself is the expressed thought of Intellect". ${ }^{55}$ In

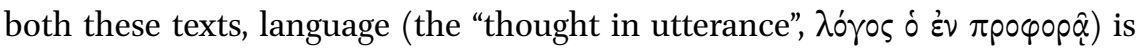

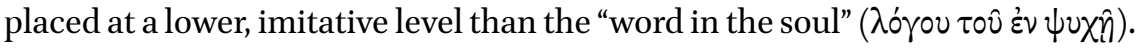
Whatever the "soul-word" is, therefore, language merely roughly approximates it, and does not exactly capture its essence precisely. Language is "below" the soul-word in hierarchical terms. It seems, given that these soul-words are explicitly described as "imitations" of the intelligibles in Intellect, that Plotinus is referring to things in the sensible world, at least as they are represented in cognition. Emilsson writes: "what is known at the level of soul is not the internal activities constituting the objects known, which are items at the level of Intellect, but external activities, that is, images, of these objects". ${ }^{56}$ Granted this, it seems that Plotinus is arguing that language operates at a lower level than sensible reality itself; the sensible world may merely be an "imitation" of the intelligibles, but language is merely an "imitation" of the sensible world. ${ }^{57}$ Language takes us even deeper back into Plato's cave than the sensible world itself. ${ }^{58}$ Another way in which this idea was expressed is in the claim that discursive reasoning is the intellect of soul - "its [soul's] intellect is in discursive reasonings". Just as Intellect is on a lower level than the One, and has lost its unity in becoming a multiplicity, ${ }^{59}$ so soul's intellect is on a lower level than the "soul-word" (that which is directly apprehended at the level of soul), and is diffused in relation to it.

However, although language represents a lower and imitative level of representation compared to the sensible world and intellect, it nonetheless plays a crucial role in relating them. Plotinus asserted that, "the reasoning power in

\footnotetext{
54 Plotinus, Enn., I.2.3 (trans. Armstrong, 137).

55 Plotinus, Enn., V.1.3 (trans. Armstrong, 19).

56 E. Emilsson (1996) 235 .

57 An interesting passage occurs in v.8.6 in which Plotinus states that Egyptian hieroglyphs "manifested the non-discursiveness of the intelligible world" and were able to represent Intellect more faithfully. However, since that time, linguistic representation had degenerated into "discourse" and "deliberation" (trans. Armstrong, 257).

$5^{8} \quad$ F. Schroeder (1996) 347.

59 See vi.7.39.
} 
soul [discursive reason] makes its judgement, derived from the mental images present to it which come from sense perception, but combining and dividing them ...." ${ }^{60}$ Discursive reason then correlates "the new and recently arrived impressions" to "those which have long been within it", that is, the remembered or intuited Forms. ${ }^{61}$ Sense-perception "gives its impression to discursive reasoning", which then "takes to pieces" what "the image-making power gave it".62 This led Plotinus to make statements which seem to place discursive reason above sense-perception but below Intellect. Discursive reason is "in the

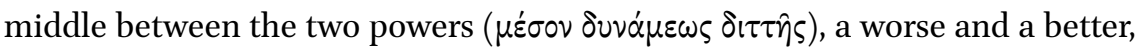
the worse that of sense-perception, the better that of Intellect". ${ }^{63}$ Discursive reason is "second after Intellect" and understands and judges "the things outside it" (that is, the sensible world). ${ }^{64}$ The Forms in Intellect are "divided" by our reasoning. ${ }^{65}$ We "do not know the whole all at once, but bring forward piece by piece and join them up again".66 Neither intellect nor sense-perception give reasons for their differentiations, this belongs to language. ${ }^{67}$

These passages seem to leave us with a paradox; in some places, Plotinus asserts that language is below both the sensible world and Intellect, but in others, he places language higher than the sensible world but below Intellect. What do we make of this? The paradox is probably only apparent. In places where Plotinus speaks of discursive reason as being higher than senseperception (primarily in Enneads v.3), he does so because of its role in making judgments about sense-perception and relating its content to the Forms in Intellect. However, he still speaks of language as taking sense-perception to pieces, which implies that the linguistic representations themselves are more multifarious and fragmentary than those in sense-perception. Since what is multifarious and fragmentary is, for Plotinus, further removed from the source, it seems that linguistic representation is still seen as in itself inferior to and imitative of sense-perception. Language is, considered as a mode of representation of reality, at a lower level than the sensible world and Intellect; but it can play a useful role in relating these two, and in that sense, can be spoken of as intermediate between them.

\footnotetext{
6o Plotinus, Enn., v.3.2 (trans. Armstrong, 75).

61 Plotinus, Enn., v.3.2 (trans. Armstrong, 77).

62 Plotinus, Enn., v.3.3 (trans. Armstrong, 77-9).

63 Plotinus, Enn., v.3.3 (trans. Armstrong, 81).

64 Plotinus, Enn., v.3.4 (trans. Armstrong, 83).

65 Plotinus, Enn., v.9.9.

66 Plotinus, Enn., VI.2.3 (trans. Armstrong, 121).

67 Plotinus, Enn., VI.3.18.
} 
Given what Plotinus said about the incomplete and partial character of linguistic description, and granted that he placed linguistic representations at a lower, imitative level than even the sensible world, it seems to follow that in his view all language is imprecise, approximate, and ultimately inadequate as a means of accurately characterizing reality. The imperfections of language are global in character, which means that discourse is never either purely univocal or entirely equivocal, but is always something in-between, regardless of what level of reality is under consideration, from the mundane to the transcendent. This is a crucial point that has widespread ramifications for understanding his thought. In this section some of the implications of his semantic theory will be explored.

According to Plotinus, language can never describe anything at all in precise, exact terms. All linguistic description is approximate in character. This is true of ordinary language, as well as metaphysical language; although the more metaphysically remote the object under discussion (the higher in the hierarchy), the more approximate the linguistic description must be. Plotinus' doctrine of language as "imitation", which regards discourse as necessarily being merely a loose indicator of reality, not a precise representation, allows him to escape the dichotomy regarding meaning in which modernity and postmodernity have become trapped: that linguistic description must be either univocal or equivocal. For Plotinus, language is useful as a "convenience of exposition" and can give a rough-and-ready sense about the reality to which it refers, but it is also in other respects misleading and inaccurate. It should not be dismissed entirely, but neither should it be taken too seriously. Even the truest statement is in some respects a falsehood. Language reveals, but in the very process of revelation it also covers up.

An interesting consequence of this theory is that whatever is said about the nature of language, must itself be merely approximate, and not precise. There just is no univocal means of speaking available to us. The metalanguage which we use to speak about language manifests the same deficiencies and imperfections as the object language. This does not entail circularity of thought. Any univocal theory of meaning must be set out by employing allegedly univocal language, but no-one thinks that this fact in itself renders the semantic theory in question self-defeating. Neither does an inadequate and approximate description of the inadequate and approximate character of language necessarily involve circularity. Bach writes: "Although for formal purposes the distinction between metalanguage and object language must be maintained, in practice one can use a language to talk about expressions in the very same 
language. One can, in Carnap's terms, shift from the material mode to the formal mode, e.g. from 'Every veterinarian is an animal doctor' to "Veterinarian" means "animal doctor."”.68 Plotinus' theory implies that we will never attain a precise linguistic description of how language works. But that is precisely the point - we can never achieve a precise linguistic description concerning anything. Implicit in this argument is the idea that the inaccuracies involved in discourse cannot themselves be pinned down or precisely specified in language. Only when we achieve a vision of Intellect, will we then non-linguistically apprehend or "see" how linguistic description falls short.

Plotinus' semantic theory derives from and is expressed in relation to his ontology. For Plotinus, as for the entire philosophical tradition of antiquity, metaphysics is primary. Furthermore, this metaphysical framework is not derived just from discursive reasoning, but rather by reasoning supplemented by means of intellectual intuition, or a non-linguistic vision of Intellect and the One. How this kind of approach might be defended in a modern context will be considered later. For the moment, it is necessary to draw out an additional feature of Plotinus' theory of language that reflects his metaphysical presuppositions. There are passages in Plotinus that hint at some form of sematic holism, which mirrors an underlying ontological holism. For example, "the specific bodies of knowledge, which lie potentially in the whole, those, that is, which grasp the specific contents, are potentially the whole ...." ${ }^{69} \mathrm{He}$ claimed that particular intellects "contain the universal Intellect". ${ }^{70} \mathrm{He}$ wrote, "In general one must think of the intelligible things as in one nature ...", "all things together in one"; "71 "all things therefore are for each other".72 Also, "each part [of Intellect], whichever one you take, is all things, but perhaps in different ways". ${ }^{73}$ Perhaps the most striking example is this: "If one enquires, therefore, where the living beings come from, one is enquiring where the sky there comes from ...." ${ }^{74}$ Implicit in these statements seems to be the idea that one cannot conceive of any particular entity except in relation to the whole. This might be taken to imply a semantic holism. If so, then Plotinus' version of semantic holism has a crucial difference to modern expressions of this theory. For Plotinus, assertions about the interrelatedness of meaning would themselves only be imperfect approximations to an ineffable reality. Any expressed theory

\footnotetext{
$68 \quad$ K. Bach (1999) 560-561.

69 Plotinus, Enn., Vi.2.20 (trans. Armstrong, 167).

70 Ibid.

71 Plotinus, Enn., vi.6.7 (trans. Armstrong, 29).

72 Plotinus, Enn., VI.7.3 (trans. Armstrong, 95).

73 Plotinus, Enn., VI.7.9 (trans. Armstrong, 115).

74 Plotinus, Enn., VI.7.12 (trans. Armstrong, 125).
} 
of semantic holism, then, like anything else specified in language, would only represent an approximation to the underlying reality of how language derives its meaning. Perhaps Plotinus might say that semantic holism, although not to be taken too literally, is the most accurate available theory concerning the interrelatedness of linguistic meaning, and is therefore to be preferred to the alternatives.

Another important implication of Plotinus' perspective on language is that logical deduction, although generally to be adhered to, can in certain cases be "overruled" by intellectual intuition. No linguistic premises are ever true in an unqualified and absolute sense, because language is not capable of that kind of exactitude. Any linguistic expression can only be true in certain respects, and what respects those are cannot be nailed down in language. It may be that a formally valid conclusion we deduce from apparently true premises actually does not hold because it draws upon some undisclosed feature of the premises that is inaccurate, even though we cannot identify the fault in language. This means that two propositions which are, if interpreted literally, contradictory, might nonetheless both be the best possible way to express the underlying reality in their respective contexts.

This point might be illustrated by using the fact that mathematicians commonly approximate the function $y=\sin (x)$ with the simpler function $y=x$ for small values of $x .^{75}$ When $x$ is small, this approximation can work very well. However, as $x$ becomes larger, the two functions diverge, and the approximation will be inaccurate, and introduce too much error into the solution. Thus, the statement $\sin (x)=x$ can be taken as approximately true, but not consistently so for any value of $x$; it is only approximately true up to a certain point (when $x$ is very small). For this analogy really to work, we must imagine that we are unable to describe mathematically the function $y=\sin (x)$, because we lack adequate concepts to do so. However, we do know, by perhaps seeing the function represented graphically, that for small values of $x$ it is very close to $y=x$. So, to express what we see in language, we say something like, "we can't say exactly what this function is, but for small values of $x$ it is close to $y=x$ ". Then we can make inferences from this, but only where $x$ is small.

Similarly, for Plotinus, logical deduction from a given set of premises can be valid in a certain direction, or for a certain number of steps, but if taken further or in another direction, the conceptual approximations inherent in the premises starts to introduce too much error into the inferences. A description of the One as "always existing" might be a good conceptual approximation in certain respects, and we can make some valid inferences from it. However, there are 
other inferences which would be valid deductively (such as "something which is always existing has a temporal history") which we must reject, because the conclusion is incorrect. The conceptual approximation "breaks down" at these points, just as the approximation $\sin (x)=x$ breaks down if $x$ is not very small. Hence, phrases such as "always existing" ( $\dot{\alpha} \varepsilon \dot{\omega} \omega \nu$ ) are used by Plotinus in relation to eternity, but he is at pains to warn that they should not be taken too literally lest incorrect inferences be drawn. ${ }^{76}$

To give another example, a person who approximates a circle by drawing a many-sided regular polygon may give a good idea of the shape in many respects, from which many valid inferences about a circle may be drawn. However, if taken as being an exact representation, incorrect conclusions could also be inferred. Similarly, if language provides only a rough imitation of reality, then while many rational inferences about that reality might be validly made from a given linguistic description, it will also be possible to draw invalid inferences. Apparent verbal contradictions which occur in different contexts might nonetheless still represent the optimal linguistic description of a reality that strictly speaking is ineffable. This does not mean that "anything goes", and that contradictions are to be permitted willy-nilly. The ultimate verdict about whether we have reached a linguistic impasse which requires two verbal descriptions which are in some respect contradictory to each other for optimal representation of the underlying reality must be based on the vision of Intellect. Intellectual intuition "does not know about propositions - they are just letters,",77 and rising above them, is able to judge them.

As noted previously, Plotinus stated that we learn about the One by means of

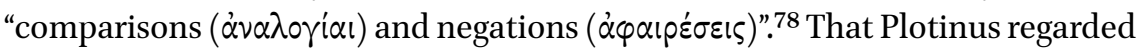
negation as a particularly apt way to describe the One is well-known. ${ }^{79}$ It is important to emphasize, however, that negative description does not constitute an exemption to the previous line of argument about all linguistic descriptions being approximate. Plotinus does not view negative descriptions as being precisely true of the One, either. Not only positive affirmations, but even negations, are inadequate to describe the Good, and even negations themselves are only insufficient half-truths when speaking of ultimate reality. ${ }^{80}$ In later Neoplatonism, this led to the idea of "negating one's negations" 81 as a necessary step in apophatic realization. Negations expressed discursively, therefore,

\footnotetext{
76 Plotinus, Enn., III.7.6.

77 Plotinus, Enn., I.3.5 (trans. Armstrong, 161).

78 Plotinus, Enn., Vi.7.36 (trans. Armstrong, 199).

79 W. Franke (2006) 63 .

80 Plotinus, Enn., vi.8.9.

81 A.H. Armstrong (1988b) 256-257 (footnote 1).
} 
are themselves only "approximate" in relation to the true nature of things. Both kataphatic ${ }^{82}$ and apophatic descriptions play a role, but both are ultimately valid only loosely, not strictly literally. Apophatic description is merely one (important) form of approximate description..$^{83}$

Similarly, the idea that descriptions of transcendent reality can be analogical in character, as suggested here by Plotinus $\left(\dot{\alpha} \nu \lambda \lambda \circ \gamma^{\prime} \alpha \iota\right),{ }^{84}$ subsequently came to take on major significance during the medieval period, especially in Western scholasticism. This development is well illustrated in the thought of Thomas Aquinas. ${ }^{85}$ Following this, the idea that metaphysical language must be analogical in nature went on to play a key role in Calvin's thought and the Reformed tradition of Protestantism, where it was virtually completely divorced from its original Platonic context. ${ }^{86}$ The legitimacy of these developments can be questioned on various grounds from a Plotinian perspective. Two crucial points might be mentioned that distinguish Plotinus' view from these later developments. Firstly, Plotinus' perspective would rule out the possibility that any such "analogical" descriptions could be completely true or without error. Anything expressed in language necessarily must contain error, including alleged scriptural texts and dogmatic proclamations of traditions and institutions. There can be no "perfect analogy". Secondly, all linguistic description, including analogy, is ultimately only useful as a dynamic tool towards liberation of the soul, not as a set of static verbal doctrines in which we may rest content. It is significant that Plotinus did not draw his philosophy from any allegedly infallible sacred text. While he does regard his system as expressing the essential doctrines of Plato, to quote Gerson, "what Plotinus thinks is of overwhelming importance for Platonism is the dynamism of the system not the mere assertion of its basic architecture". ${ }^{87}$

It might be objected that the view that all language statements necessarily contain error is self-referentially inconsistent. However, this is not so. Certainly, it follows that the statement "all language statements necessarily contain error", itself must embody error, and not be a perfect representation of the underlying relation between language and reality. But it may still be the most accurate expression possible in language in this respect. In other words, any alternative description, such as the opposite statement, "some language

\footnotetext{
$82 \quad$ N. Banner (2018) 221-223.

83 This over-emphasis on the centrality of apophasis can be seen in various recent appropriations of Neoplatonism in both religious and secular contexts. W. Franke (2013) $5^{8-63}$.

84 Plotinus, Enn., vi.7.36.

85 A.P. Darley $(2016) 312$.

86 A.R. Haig (2015) 266-268.

$87 \quad$ L.P. Gerson $(2016) 73$.
} 
statements do not contain any error", may be even more misleading, perhaps much more so. Thus, although "all language statements necessarily contain error" is not perfectly true, it is as close to true as can be obtained in language, and that is all we can ever hope for. We need to move beyond language to a non-linguistic medium of representation, the Forms in Intellect, if we are to see things as they really are.

It follows from Plotinus' theory that what is the "optimal" description in relation to a particular reality is not absolute, but rather, is relative to the starting point or perspective of the one engaged in dialogue. Which description is best to use is determined in part by the context in which it occurs. So, as has been noted, apparently contradictory claims (if interpreted literally) can nonetheless both be optimally true within their respective contexts. Given that context is fluid and always changing, it follows from this that philosophical discourse must be a dynamic, not a static, phenomenon. This leads us to Plotinus' concept of dialectic.

\section{Mystical Intersubjectivity and Dialectic as Ostension Towards} the Transcendent

True philosophical reasoning, according to Plotinus, is "dialectic" ( $\delta 1 \alpha \lambda \varepsilon \kappa \tau i x \eta ́)$. As has already been noted, dialectic is not a slave to deductive reasoning. Dialectic "leaves what is called logical activity, about propositions and syllogisms, to another art ... Some of the matter of logic it considers necessary, as a preliminary, but it makes itself the judge of this, as of everything else, and considers some of it useful and some superfluous ....".88 The overarching concern is not logical consistency at every point, but to paint a picture which is the best possible approximation to something which cannot be expressed in words precisely at all. This is the only way that we can achieve Plato's aim to carve up reality "where the natural joints are". ${ }^{89}$ In all things, the guide is a vision of Intellect, because "seeing and that which has seen are not reason, but greater than reason and before reason and above reason, as is that which is seen". ${ }^{90}$ The final ascent to achieve realization of the One is "not by way of reasoned knowledge or of intellectual perception ... but by way of a presence superior to knowledge". ${ }^{91}$

\footnotetext{
88 Plotinus, Enn., I.3.4 (trans. Armstrong, 159).

89 Plato, Phaedrus, $265 \mathrm{e}$ (trans. Fowler, 535).

90 Plotinus, Enn., vi.9.10 (trans. Armstrong, 339).

91 Plotinus, Enn., VI.9.4 (trans. Armstrong, 315).
} 
The real purpose of discourse, therefore, is not just to "make statements", but to engender some idea and understanding of what is being said. ${ }^{92}$ True knowledge is not found in propositional descriptions of a thing, but in apprehension of the thing itself; it is "not thought in the sense of being a definition of the thing or an intuition of it, but the thing itself in the intelligible". ${ }^{93}$ This understanding can only ultimately come through intellectual intuition of the Forms. ${ }^{94}$ It is necessary for the seeker after truth to "abandon the verbal signification and grasp the meaning of what is being said". ${ }^{95}$ Language, then, when employed correctly (that is, dialectically), is a tool intended to point the hearer towards a vision of Intellect. Therefore, dialectic could be called "ostension towards the transcendent"; it is a means of verbally pointing out metaphysical realities that can be "seen" and "intuited", much like saying "look at that!" in ordinary speech directs the hearer towards a view of some object. Dialectic acts "as if showing the way to someone who wants to have a view of something". ${ }^{96}$ To use Wittgenstein's famous analogy, dialectic is elucidatory, a ladder upon which to climb up to see the world aright. ${ }^{97}$ However, unlike Wittgenstein's ladder, one does not throw dialectic away entirely once one has reached the top (by achieving a vision of Intellect and the One). The propositions of dialectic are not senseless, as Wittgenstein viewed his own propositions in the Tractatus; they are just imperfect, partial, and weak. They serve a necessary purpose: "We must use these [temporal] words because we are compelled to want to signify our meaning". 98

Even once a person has reached a vision of the transcendent, and then "lets all study go",99 it will still be necessary to resort to dialectic in order to guide others towards the truth. Engaging in dialectical reasoning assists all those engaged to mutually achieve a vision of the Forms. It is possible to fail to attain to a vision of the One because of a "lack of a reasoning to guide him and give him assurance about the One". ${ }^{100}$ Plotinus did not directly address issues of social order or politics in his writings in the way that is found in Plato, but it is reasonable to infer from his description of the person "who has not come to the vision, and his soul has no awareness of the glory there", due to

\footnotetext{
92 Plotinus, Enn., vi.2.3 (trans. Armstrong, 121).

93 Plotinus, Enn., vi.6.6 (trans. Armstrong, 27).

94 D. Piętka (2015) 24.

95 Plotinus, Enn., VI.4.2 (trans. Armstrong, 279).

96 Plotinus, Enn., vi.9.4 (trans. Armstrong, 317).

97 L. Wittgenstein (1974) 89.

98 Plotinus, Enn., v.8.12 (trans. Armstrong, 279).

99 Plotinus, Enn., VI.7.36 (trans. Armstrong, 201).

100 Plotinus, Enn., VI.9.4 (trans. Armstrong, 317).
} 
various forms of "impediment" blocking any ascent towards a vision of the transcendent, ${ }^{101}$ that he shares something of Plato's intellectual elitism. ${ }^{102}$ The supreme vision is reached by means of an "inner sight" that "everyone has but few use". 103 Not everybody may be able to benefit from dialectic. However, as has already been mentioned, Plotinus noted a close relationship between metaphysical dialectic and mythology, and he attributes to mythology a similar role of pointing to ineffable transcendent realities. ${ }^{104}$ This might imply that mythology, and perhaps also religious texts and sacred scriptures, although not philosophical dialectic, can serve a similar function, if they are not interpreted too literally, but as pointing to a deeper underlying reality. These might provide alternative pathways for an ascent to a vision of the One. This could only be so, however, if, the approach to these religious texts did not take the form of a supposedly literal interpretation yielding a static orthodox dogma, but instead, took the statements in scripture in a sense which facilitated a dynamic ascent of the soul. The aim would be to transcend or escape the scriptural text, not to become imprisoned by it.

One of the main criticisms of all forms of mysticism is that, because mystical awareness is often portrayed as private and subjective, it cannot form the basis for any metaphysical claim. This is often couched in terms of Wittgenstein's famous "private language argument". ${ }^{105}$ This objection fails completely in the case of Plotinus' theory. He held that the Forms in Intellect are "public" and not private in the sense that, just as multiple viewers can perceive a particular object from different perspectives in sense-perception, so multiple "observers" can perceive the same underlying Form in Intellect through reflection on their sense-perceptions of the same object. Even though only a minority of people actually employ this higher vision, these people inhabit the same transcendent world and can communicate about it - "They [the Forms] exist and appear to us and he who sees them cannot possibly say anything else except that they are what really exists" ${ }^{106}$ The intuitions of the various observers are "coordinated" in contemplation of the same Form by means of its image in sense-perception, providing a genuine intersubjectivity of higher awareness. People do not perceive "in the same way", but some who look at a sensible object recognize the underlying Form, while others do not. ${ }^{107}$ Those who do are "carried to that

\footnotetext{
101 Ibid.

102 C. Bobonich (2002) 2-3.

103 Plotinus, Enn., I.6.8-9 (trans. Armstrong, 259).

104 Plotinus, Enn., III.5.9.

105 L. Wittgenstein (2001) $75^{-88 .}$

106 Plotinus, Enn., I.6.5 (trans. Armstrong, 247).

107 Plotinus, Enn., II.9.16 (trans. Armstrong, 289).
} 
higher world". ${ }^{108}$ It is significant that, for Plotinus, the world of Intellect is just as real and accessible as the world of sense, and he talks about them in similar terms: someone who cannot see the Forms "would neither have understood this world here nor seen that higher world".109 These two worlds are integrally related: "if one means 'things in the universe', including soul and the things in soul, all the things are here below which are in the intelligible world".110 Those who are sufficiently liberated to attain to an apprehension of the Forms, thereby come to inhabit the same "higher world", involving a shared mystical intersubjectivity. The extreme limit of this intersubjectivity is the "vision of the One", which can only be held in a single unified vision. ${ }^{111}$

\section{Conclusion: The Relevance of Plotinus in a Contemporary Context}

Having presented an interpretation of the perspective on language expressed in the Enneads, it is worth noting, in concluding, that this theory lends itself, in a modern context, to a proof by contradiction. This argument relies upon the claim made by some scholars, which will not be defended here, that contemporary "postmodern" philosophy implies that discursive reason functioning on an autonomous basis can establish nothing whatsoever. ${ }^{112}$ As Jacobi foresaw, and Nietzsche celebrated, the inevitable endpoint of modern/postmodern Western thought is "nihilism". ${ }^{113}$ Contemporary philosophy is ready, willing and able to "deconstruct" (Derrida ${ }^{114}$ ), or to exorcise and render senseless by means of philosophical "therapy" (the later Wittgenstein ${ }^{115}$ ), any proposed rational system or metaphysical claim. However, it is utterly unable to legitimately present anything positive in its place, without becoming inconsistent. Whatever positive construction is put forward is equally susceptible to deconstruction, even if the practitioners of postmodern thought wish to determinately proceed as if this were not so, as if there was somewhere still to go when the end of the road has been reached. This seems to amount to a proof by contradiction that the foundational approach of both modern and postmodern

\footnotetext{
108 Plotinus, Enn., II.9.16 (trans. Armstrong, 291).

109 Plotinus, Enn., II.9.16 (trans. Armstrong, 291).

110 Plotinus, Enn., v.9.13 (trans. Armstrong, 317).

111 P. Hadot (1993) 32-33.

112 J. Milbank (1999) 32.

113 "I will describe what happens next, what must necessarily happen: the triumph of Nihilism". F.W. Nietzsche (1964) 1.

114 J. Derrida (1991) 41.

115 L. Wittgenstein (2001) 44.
} 
philosophy, a total reliance on discursive reason, is not a reliable means of arriving at truth. If, using autonomous discursive reason, we must inevitably reach the conclusion that this very reason is incapable of proving anything at all, then we have reached a conclusion which contradicts the assumed starting point, that discursive reason is valid as a means of attaining knowledge. This serves as a proof by contradiction that discursive reason must be supplemented by, or grounded in, some other source or modality of knowledge. In the words of Plotinus, "how is it possible for that not to exist without which it is not possible to think or speak?"116

Plotinus' theory provides us with a compelling account of why discursive reason alone, without the illumination of intellectual intuition, will fail as a methodology. Because language is only "approximate" in relation to ultimate reality, then without any other means of insight into the nature of that reality, we will constantly take wrong turns, even by following formally valid arguments. The entire modern/postmodern paradigm of philosophy is misconceived. However, he does more than this; he also provides us with the most viable option for a solution to the dilemma. If reason must be grounded in some other mode of knowledge, the most plausible candidate for that alternative source of knowledge, is illumination by means of non-discursive "intuition" or a vision of Intellect and the One. In Plotinus' view, this is not subjective, but involves access to a "higher world" which can form the basis for intersubjective agreement between multiple different seers. There is, in fact, reason to believe that such intersubjective mystical agreement is possible. One important piece of evidence is the striking parallels between Presocratic and Platonic thought in Greece, and Vedic and Upanishadic thought in India, before any significant interaction between these two cultures was initiated through the career of Alexander the Great. ${ }^{117}$ Another example is the way in which Neoplatonism was so readily and naturally adaptable to a Jewish, ${ }^{118}$ Christian, ${ }^{119}$ and Islamic ${ }^{120}$ intellectual milieu. This appropriation of Neoplatonism occurred not merely in a mystical context (although it certainly did), but even within the framework of doctrinaire theological orthodoxy. That a marginal, heterodox mystic like Jakob Böhme might find inspiration in Neoplatonism seems unremarkable; yet even such stalwarts of orthodoxy as Augustine ${ }^{121}$ and Thomas Aquinas ${ }^{122}$

\footnotetext{
116 Plotinus, Enn., Vi.6.13 (trans. Armstrong, 51).

117 J. Bussanich (2005) 5-7.

118 G. Scholem (1974) 87-91.

119 J. Rist (1996) 408.

120 M. Fakhry (2002) 77-82.

121 J. Rist (1996) 404-408.

122 W.J. Hankey (2019) 14.
} 
found it amenable to draw upon Neoplatonist thought. That there are significant differences between early Greek and Indian thought, and between Jewish, Christian and Islamic theology, is undeniable. But there also seems to be such a convergence of resemblances as to raise questions about whether these might reflect a common vision of a Plotinian "higher world" expressed within different cultural and religious contexts.

This paper has surveyed Plotinus' doctrine of language in relation to his metaphysics as set forth in the Enneads. Plotinus' view of language, as interpreted here, is that it plays a secondary and derivative role in attempting to approximate what is known non-linguistically by means of intellectual intuition, or a vision of the Forms. This does not rule out a role for rational inference or deductive proofs, but it recognizes that all such rational inference is valid only insofar as it continues to result in the optimal possible imitation of the mystical vision. Otherwise, we may be led astray by the inadequacy of our linguistic concepts. This implies that while discursive reason might play an essential role in directing enquirers towards the transcendent vision (if it is done correctly, that is, dialectically), there are some things that they can at best only take on faith, or as only very faintly conceived, until they have experienced this vision for themselves. The dialectical process has the right to "overrule" strictly logical deduction at certain points. Dialectic is ostension towards the transcendent. The idea of a "mystical intersubjectivity" inherent in Plotinus' doctrine of intellectual intuition has also been explored. Finally, an argument was advanced that Plotinus equips us with the foundations for a telling critique of modern and postmodern philosophy and provides a means of escape from the intellectual morass that besets contemporary thought and culture.

\section{References}

Archer-Hind, R.D. 1888. The Timaeus of Plato. Edited and translated by R.D. Archer-Hind. London: Macmillan.

Armstrong, A.H. 1989. Plotinus, Porphyry on Plotinus \& Ennead I, revised edition. Edited and translated by A.H. Armstrong. Loeb Classical Library vol. 440. Cambridge, MA: Harvard University Press.

Armstrong, A.H. 1966. Plotinus, Ennead II. Edited and translated by A.H. Armstrong. Loeb Classical Library vol. 441. Cambridge, MA: Harvard University Press.

Armstrong, A.H. 1993. Plotinus, Ennead III, corrected edition. Edited and translated by A.H. Armstrong. Loeb Classical Library vol. 442. Cambridge, MA: Harvard University Press.

Armstrong, A.H. 1984a. Plotinus, Ennead IV. Edited and translated by A.H. Armstrong. Loeb Classical Library vol. 443. Cambridge, MA: Harvard University Press. 
Armstrong, A.H. 1984b. Plotinus, Ennead V. Edited and translated by A.H. Armstrong. Loeb Classical Library vol. 444. Cambridge, MA: Harvard University Press.

Armstrong, A.H. 1988a. Plotinus, Ennead VI.1-5. Edited and translated by A.H. Armstrong. Loeb Classical Library vol. 445. Cambridge, MA: Harvard University Press.

Armstrong, A.H. 1988b. Plotinus, Ennead VI.6-9. Edited and translated by A.H. Armstrong. Loeb Classical Library vol. 468. Cambridge, MA: Harvard University Press.

Bach, K. 1999. 'Metalanguage'. In The Cambridge Dictionary of Philosophy, 2nd edition, edited by R. Audi, 560-561. Cambridge: Cambridge University Press.

Banner, N. 2018. Philosophic Silence and the 'One' in Plotinus. Cambridge: Cambridge University Press.

Benitez, E.E. 1995. 'The Good or the Demiurge: Causation and the Unity of Good in Plato'. Apeiron 28: 113-40.

Betz, J.R. 2012. After Enlightenment: The Post-Secular Vision of J.G. Hamann. Malden, MA: Wiley-Blackwell.

Bobonich, C. 2002. Plato's Utopia Recast: His Later Ethics and Politics. Oxford: Clarendon Press.

Bussanich, J. 2005. 'The Roots of Platonism and Vedānta: Comments on Thomas McEvilley'. International Journal of Hindu Studies 9: 1-20.

Dan, J. 2002. 'Introduction'. In The Heart and the Fountain: An Anthology of Jewish Mystical Experiences, edited by J. Dan, 1-48. Oxford: Oxford University Press.

Darley, A.P. 2016. 'Predication or participation? What is the nature of Aquinas' doctrine of analogy?.' The Heythrop Journal 57: 312-324.

Derrida, J. 1991. A Derrida Reader: Between the Blinds. Translated by P. Kamuf. New York: Columbia University Press.

Emilsson, E.K. 1996. 'Cognition and its object'. In The Cambridge Companion to Plotinus, edited by L.P. Gerson, 217-249. Cambridge: Cambridge University Press.

Fakhry, M. 2002. Al-Fārābi, Founder of Islamic Neoplatonism: His Life, Works and Influence. Oxford: Oneworld Publications.

Fowler, H.N. 1914. 'Plato, Phaedrus'. In Plato: Euthyphro, Apology, Crito, Phaedo, Phaedrus. Edited and translated by H.N. Fowler, 412-579. Loeb Classical Library vol. 36. Cambridge, MA: Harvard University Press.

Franke. W. 2006. 'Apophasis and the Turn of Philosophy to Religion: From Neoplatonic Negative Theology to Postmodern Negation of Theology'. International Journal for Philosophy of Religion 6o: 61-76.

Franke, W. 2013. 'Apophasis as the common root of radically secular and radically orthodox theologies'. International Journal for Philosophy of Religion 73: 57-76.

Gatti, M.L. 1996. 'Plotinus: The Platonic tradition and the foundation of Neoplatonism'. In The Cambridge Companion to Plotinus, edited by L.P. Gerson, 10-37. Cambridge: Cambridge University Press. 
Gerson, L.P. 2016. 'The "Neoplatonic” interpretation of Plato's Parmenides', International Journal of the Platonic Tradition 10: 65-94.

Hadot, P. 1993. Plotinus or The Simplicity of Vision. Translated by M. Chase. Chicago: The University of Chicago Press.

Haig, A.R. 2015. 'Modernity, "Radical Orthodoxy", and Cornelius Van Til: A journey of rediscovery of participatory theism'. Colloquium: The Australian and New Zealand Theological Review 47: 257-273.

Hankey, W.J. 2019. Aquinas's Neoplatonism in the Summa Theologiae on God: A Short Introduction. South Bend, IN: St Augustine's Press.

Holbrow, C.H., Lloyd, J.N., Amato, J.C., Galvez, E., \& Parks, M.E. 2010. Modern Introductory Physics, 2nd ed. New York: Springer.

Jowett, B. 1953. 'Plato, Critias'. In The Dialogues of Plato, 4th ed., vol. 3. Edited and translated by B. Jowett. Oxford: Clarendon Press.

Milbank, J. 1999. 'Knowledge: The theological critique of philosophy in Hamann and Jacobi'. In Radical Orthodoxy: A New Theology, edited by J. Milbank, C. Pickstock \& G. Ward, 21-37. London: Routledge.

Nietzsche, F.W. 1964. The Will to Power: An Attempted Transvaluation of All Values, vol. 1. Translated by A.M. Ludovici. New York: Russell and Russell.

O'Meara, D.J. 1996. 'The hierarchical ordering of reality in Plotinus'. In The Cambridge Companion to Plotinus, edited by L.P. Gerson, 66-81. Cambridge: Cambridge University Press.

Piętka, D. 2015. 'The concept of intuition and its role in Plato and Aristotle'. Organon 47: $23-40$.

Rist, J. 1996. 'Plotinus and Christian philosophy'. In The Cambridge Companion to Plotinus, edited by L.P. Gerson, 386-413. Cambridge: Cambridge University Press.

Scholem, G. 1974. Kabbalah. New York: Meridian.

Schroeder, F.M. 1996. 'Plotinus and language'. In The Cambridge Companion to Plotinus, edited by L.P. Gerson, 336-355. Cambridge: Cambridge University Press.

Wittgenstein, L. 1974. Tractatus Logico-Philosophicus, rev. ed. Translated by D.F. Pears \& B.F. McGuinness. London: Routledge Classics.

Wittgenstein, L. 2001. Philosophical Investigations, 3rd ed. Translated by G.E.M. Anscombe. Malden, MA: Blackwell Publishing. 